\title{
Use of Phytotherapics, Low Power Laser and Ozone for Biting Wound in Dog
}

\author{
Paulo Geovane de Cantuário Ferreira', Leonardo Inocêncio Cunha', \\ Pâmella Gomes Rabelo', Any Tâmara da Silva Rocha ${ }^{2}$, André Giarola Boscarato³, \\ Luiz Romulo Alberton ${ }^{3} \&$ Carla Faria Orlandini de Andrade ${ }^{1}$
}

\begin{abstract}
Background: Skin wounds are among the most common cases in small animals, highlighting the importance of alternative therapies as an aid to the healing process. These include ozone, which has a bactericidal and immunomodulatory action; the low power laser that determines photodynamic changes triggering metabolism elevation; and the use of medicinal plants, in which several herbal medicines has been mentioned in research relating their benefits to wound healing in humans and animals. Thus, it aims to report the case of a dog submitted to these treatments due to chronic wound due to bite.

Case: A 6-year-old canine, female, mixed-breed, $8 \mathrm{~kg}$, with a perforating wound in the left anterior limb in the scapular and humeral region, caused by trauma from the bite of another dog, previously treated, without clinical improvement, has been attended presenting apathy, increased body temperature $\left(40.1^{\circ} \mathrm{C}\right)$, difficulty in walking and inability to support the injured limb, which was swollen, hyperemic, with elevated temperature, absence of hair, elevated pain sensitivity and presence of 2 circular lesions, approximately $2 \mathrm{~cm}$ in diameter, caused by trauma, and others of size between 0.5 and $1 \mathrm{~cm}$ in diameter, which appeared during the course of the disease, characterized as fistulas, through which there was drainage of characteristic fluid exudative and purulent discharge. It was collected blood sample for blood count and purulent material through sterile swab for culture and antibiogram. Systemic treatment with ceftiofur, dipyrone, meloxican and topical cleaning of the wounds with hydrogen peroxide and physiological solution; dimethyl sulfoxide ointment, and hot compresses was chosen. After seven days, the animal showed significant general clinical improvement and in the limb, it was observed: decreased edema, hyperemia, hyperthermia and secretions, with no pus. Only local treatment was recommended, with cleansing of the skin lesions, with physiological solution, chlorhexidine and healing gel made of herbal medicine: chitosan, aloe vera, marigold, sunflower oil and barbatimao. After 21 days of treatment, the injured limb showed consecutive clinical improvement, with epithelialization of the smaller diameter lesions. Low-level laser and ozone therapy was instituted, totaling three initial sessions every five days and one last session 14 days after the third. After the four sessions the animal was discharged, presenting absence of the previously reported alterations, besides the total re-epithelialization of the lesions and hair growth.

Discussion: The contamination arising from bite can interfere with healing time due to the action of bacterial toxins and inflammatory infiltrates that cause vascular and cellular damage. According to other reports the use of ozone therapy, local and systemic, promoted rapid healing, related to effective decontamination, in a short period of time. Considering the response and quality of tissue repair, due to wound recovery, verifying therapeutic effects of anti-inflammatory action, effective decontamination, stimulation of granulation tissue, epithelialization and repilation of the cutaneous region, it is concluded that topical and systemic ozone therapy, associated with the effect of tissue regeneration by edge revival in chronic lesions, of low power laser and herbal medicine gel, under the conditions of this case, represent satisfactory therapy for the treatment of bite wounds in dogs.
\end{abstract}

Keywords: alternative therapy, healing, ozone therapy, second intention healing. 


\section{INTRODUCTION}

The number of skin wounds in small animals are high [19], most of which are contaminated [10]. The healing process involves an association of physiological events at the cellular level, and any interference culminates in delayed wound healing and chronicity [2].

Ozone therapy can trigger local, regional and/ or systemic effects, depending on the quantity, concentration and route of application [18]. This gas can inactivate microorganisms in addition to inhibiting their reproductive cycle [4], comprising an important therapy for the disinfection of infected wounds [26]. In addition, ozone therapy promotes immunomodulatory action and improves blood circulation, leading to adequate oxygenation of injured tissues [1].

The main therapeutic effects of low-power laser are related to stimulating and activation of lymphocyte proliferation, increased phagocytosis of macrophages, increased secretion and activation of growth factors, influencing fibroplasia and intensifying the reabsorption of fibrin and collagen [3], in addition to promoting an increase in blood flow and lymphatic drainage, resulting in less local edema [8,12].

The use of medicinal plants to aid wound healing has been frequent in veterinary medicine, with several studies involving phytotherapics for the most diverse purposes, emphasizing its benefits to the healing process [7,24].

The aim of this study is to report the treatment performed for the healing of contaminated skin wounds in a dog, based on the use of alternative therapies.

\section{CASE}

A 6-year-old canine, female, mixed-breed and medium size $(8 \mathrm{~kg})$, had a perforating wound on her left anterior limb, caused by trauma resulting from the bite of another dog, in the scapular and humeral region. The animal had previously been treated, by another professional, with non-steroidal anti-inflammatory, meloxicam $\left(0.2 \mathrm{mg} / \mathrm{kg} \text { - Maxicam } 0.2 \%{ }^{\circledR}\right)^{1}$, antibiotic, amoxicillin $\left(20 \mathrm{mg} / \mathrm{kg} \text { - Agemoxi } \mathrm{CL}^{\circledR}\right)^{2}$, for seven days, and later cephalexin $(30 \mathrm{mg} / \mathrm{kg}$ - Celesporim $\left.250 \mathrm{mg}^{\circledR}\right)^{1}$, for 14 days, and topically with a commercial healing ointment based on gentamicin, sulfanilamide, sulfadiazine, urea and vitamin A (Vetaglós $\left.{ }^{\circledR}\right)^{3}$. Without clinical improvement, with evolution of 30 days since the initial trauma, the animal was taken for a second visit, presenting as clinical changes: apathy, increased body temperature $\left(40.1^{\circ} \mathrm{C}\right)$, difficulty in walking and inability to support the injured limb, which presented swollen, hyperemic, with high temperature, absence of hair, high painful sensitivity and the presence of 2 circular lesions approximately $2 \mathrm{~cm}$ in diameter, which, according to the owners, were caused by the trauma, and several others in size between 0.5 and $1 \mathrm{~cm}$ in diameter, which appeared during the evolution of the condition, characterized as fistulas, through which there was drainage of liquid with an exudative characteristic and purulent secretion (Figure 1).

It was taken blood samples for blood count and biochemicals (ALT, FA, urea and creatinine) and purulent material, using a sterile swab, for culture and antibiogram. The laboratory alterations included leukocytosis with deviation to the left and the growth of the bacterium Pseudomonas aeruginosa, with sensitivity to all tested antibiotics, including the active ingredients that had already been used in the initial treatment of the animal. It was chosen the treatment with ceftiofur $\left(2.2 \mathrm{mg} / \mathrm{kg} \text { - AcurA }{ }^{\circledR}\right)^{4}$, intramuscularly, every $24 \mathrm{~h}$, for 5 days; dipyrone $\left(25 \mathrm{mg} / \mathrm{kg} \text { - } \text { Dipimed }^{\circledR}\right)^{5}$, orally, every $8 \mathrm{~h}$, for 3 days, meloxicam $(0.2 \mathrm{mg} / \mathrm{kg}$ initially and then $0.1 \mathrm{mg} / \mathrm{kg}$ - Maxicam $\left.0.5 \mathrm{mg}^{\circledR}\right)^{1}$, every $24 \mathrm{~h}$, for 5 days, and topical treatment with cleaning of the wounds with hydrogen peroxide and

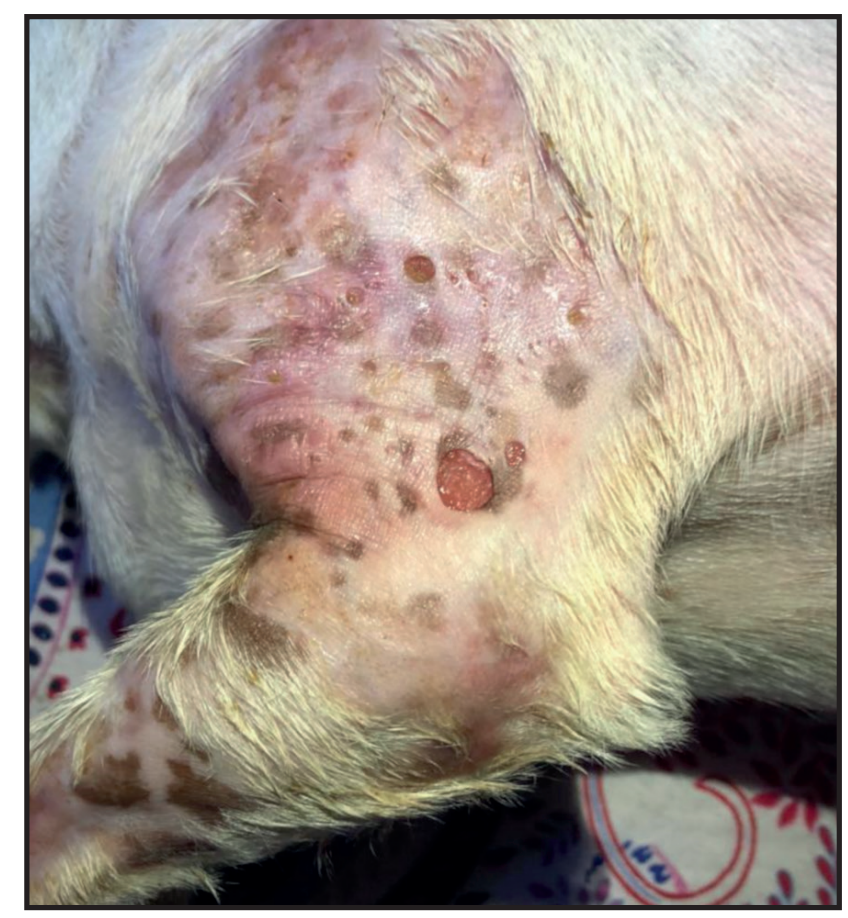

Figure 1. Canine animal presenting wound on the left anterior limb, resulting from a bite, with major circular lesions, caused by primary trauma, and minor, caused secondary by infection and local infection, characterized as fistulas. 
physiological solution; ointment based on dimethyl sulfoxide $\left(\mathrm{DM}-\mathrm{Gel}^{\circledR}\right)^{3}$, every $12 \mathrm{~h}$, and hot compresses, every $8 \mathrm{~h}$, for $15 \mathrm{~min}$. After 7 days, the animal showed significant general clinical improvement and could be observed in the limb: decreased edema, hyperemia, hyperthermia and secretions, with no pus. Only local treatment was recommended, with cleansing of skin lesions, with physiological solution, chlorhexidine $0.5 \%$ and healing gel manipulated based on herbal medicines: chitosan $2 \%$, aloe vera $5 \%$, calendula $5 \%$, sunflower oil $5 \%$ and barbatimao 5\%.

After 21 days of treatment, the injured limb showed consecutive clinical improvement, with a moderate amount of edema and exudative secretion remaining, as well as the absence of hair growth and epithelialization of larger diameter lesions (Figure 2).

Low-level laser and ozone therapy was instituted, totaling three initial sessions every five days and one last session 14 days after the third. In the first session, a laser (dose $1 \mathrm{~J}$ ) was performed at the edges of the wounds and fistulas, intrarectal ozone (concentration of $18 \mathrm{mg} / \mathrm{L}$, totaling $60 \mathrm{~mL}$ ), topical, through the bagging technique, (concentration of $45 \mathrm{mg} / \mathrm{L}$,

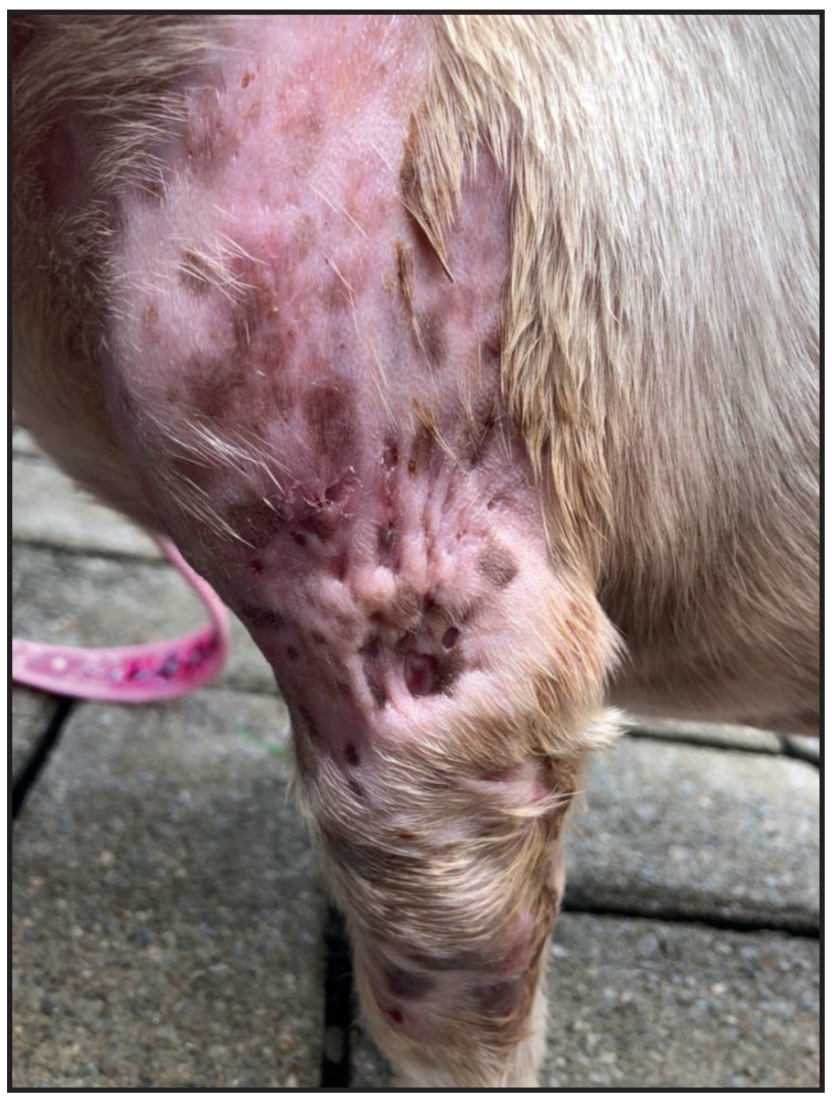

Figure 2. Canine animal presenting a wound on the left anterior limb, resulting from a bite, after 21 days of treatment with conventional therapies and herbal medicines. for $20 \mathrm{~min}$ ) and via ozonated auto-hemotherapy (concentration of $40 \mathrm{mg} / \mathrm{L}$, using the VG14 section for application); in the second session, intrarectal ozone (concentration of $26 \mathrm{mg} / \mathrm{L}$, totaling $60 \mathrm{~mL}$ ), topical, through the bagging technique (technique previously described) and intravenous, using $200 \mathrm{~mL}$ of ozonated ringer lactate (concentration of $65 \mathrm{mg} / \mathrm{L}$ ); in the third session, intrarectal and intravenous ozone was performed (techniques described previously), and through the bagging technique (concentration of $38 \mathrm{mg} / \mathrm{L}$, for $20 \mathrm{~min}$ ); in the fourth and last session, the technique of intrarectal ozone therapy and bagging was repeated (techniques previously described).

To perform laser therapy, the Luminex Vet ${ }^{\circledR 6}$ Class 3B device was used, with punctuations from $500 \mathrm{~mW}$ to $1000 \mathrm{~W}$, with an $808 \mathrm{~nm}$ point probe, at $500 \mathrm{~mW}$ (dose 1J). For ozone therapy, the ozone generator used was O\&L1.5RM ${ }^{\circledR 7}$.

After the four sessions, the animal was discharged, with the absence of the previously reported changes, in addition to the total re-epithelialization of the lesions and hair growth (Figure 3).

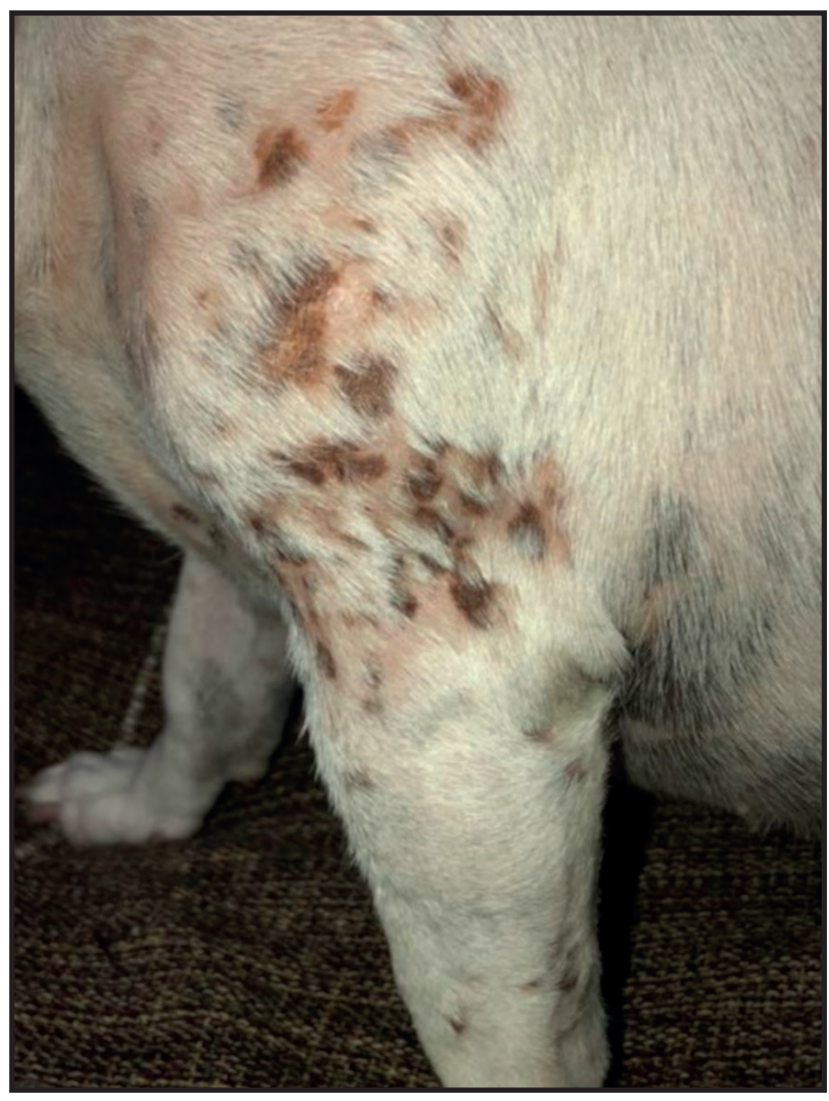

Figure 3. Canine animal presenting complete wound healing on the left anterior limb, resulting from a bite, and hair growth, after treatment with low-power laser and ozone therapy. 


\section{DISCUSSÃO}

The healing process of contaminated wounds is delayed due to the action of bacterial toxins and inflammatory infiltrates, which cause cell necrosis and thrombosis, which increases the time for tissue repair, corroborating with the present report, where small diameter skin lesions presented chronic inflammation and slow healing [13].

Countless studies point out the benefits of using herbal medicines in the healing process, in humans and animals, relating their therapeutic characteristics to the active principles of each product, supporting the use in the case in question. We opted for the combination of active ingredients in manipulated gel, aiming at a more watery and refreshing final product, increasing absorption, minimizing irritation on already inflamed tissues and contributing to the realization of bandage, taking into account the hot climate of the region and the animal discomfort caused by the use of oily creams. The herbal medicines choice was based on positive results already published: differentiating, in some cases, the concentration of some assets due to the combination of more than one therapeutic principle, mentioning barbatimao [20], marigold [15], aloe vera [16], calendula and sunflower [29] and chitosan [25]. In contrast, there are reports showing that the contribution of herbal medicines, on the healing process, is not always sufficient to accelerate the closure of skin wounds, as with aqueous extract of Calendula officinalis in rats, justifying that the concentration and form of use of the active, as well as the degree of the lesion, interfere in this benefit, often being inefficient when used in isolation [17]. This study corroborates the results of the case described where topical treatment with herbal gel was beneficial, but not sufficient for the healing of chronic lesions.

The stimulating effect of laser therapy on tissue regeneration is related to the influence on cell mitosis, keratinocyte migration and neoangiogenesis, anti-inflammatory and analgesic effect [3]. Therefore, this technique is able to promote a revival of the edges of the wounds, as long as appropriate frequencies and doses are used, so that cell proliferation modulation occurs. According to the authors, in the case reported, the low power laser was used in the first session, aiming to revitalize the epithelial edges of the lesions, restarting the healing process that was chronic and involutive.

The low-power laser can stimulate biological and regenerative mechanisms, and most of the registered effects are related to the proliferation of cells, mainly fibroblasts [5]. In rats, laser therapy promoted angiogenesis and decreased the inflammatory infiltrate in surgical wounds, indicating the effectiveness and contribution of therapy in healing [23].

Ozone, when used topically, has antiseptic action, making it a therapeutic option for chronic skin infections, including cases of contamination by multi-resistant bacteria, in addition to stimulating healing, increasing cell renewal [6]. Therefore, the bagging technique was chosen in all sessions, influencing a greater amount of gas directly on the injured tissues.

The use of ozone therapy, local and systemic, in extensive skin wounds in dogs, promoted rapid healing, related to effective decontamination, in a short period of time, and the consequent growth of granulation tissue, with a reduction of the lesion area from 40 to $50 \%$ between 15 and 30 days [9], with the techniques and results described by the authors, according to the present report, where the local and systemic association of ozone culminated in a reduction in the time of skin healing. The administration of ozone in a systemic manner allows the release of $\mathrm{O} 2$ to the tissues, which improves blood circulation and, thus, energy metabolism, resulting in the release of growth factors that contribute to tissue repair $[21,27,28]$.

$\mathrm{O} 3$ has an anti-inflammatory action by blocking the expression of COX2, with short-term effect, and also analgesic action, in the long term, arising from an antioxidant mechanism [11,22]. These studies emphasize the result observed in the present report, where allopathic anti-inflammatory drugs, such as meloxicam and dimethyl sulfoxide, were not sufficient to control the local inflammatory process, with a great improvement after the institution of ozone therapy.

The therapeutic effects of the ozone gas utilization technique are directly related to adequate doses and exposures, at appropriate time intervals, being critical factors in the treatment of skin wounds, for the reduction of healing time [8]. The ozone concentration used, in the present case, for the intrarectal administration technique, in the first session, corroborates with another report, with variation between doses, using $7.5 \mathrm{~mL} / \mathrm{kg}$ compared to 2 to $3 \mathrm{~mL} / \mathrm{kg}$ described by the authors [9]. The other sessions were carried out using the concentration of $26 \mathrm{mg} / \mathrm{L}$, while the same authors chose to remain with the concentration initially used, with equally satisfactory results. When comparing the 
bagging technique, with the same study previously discussed, concentrations and intervals between sessions are slightly higher here. Still in discussion with the results presented in the same report, the authors used the technique of intramuscular autohemotherapy weekly, in concentrations lower than that described in this report, for seven weeks, aiming at an immunomodulatory effect. In this case, we opted for auto-hemotherapy in a single dose with higher gas concentration, a technique called greater ozonated auto-hemotherapy, stating that the concentration can range from 15 to $70 \mathrm{mg} / \mathrm{L}$, depending on the patient's condition and illness. [14].

In addition to complete re-epithelialization of lesions and resolution of clinical signs, total repilation of the previously affected area was observed. This result may be related to the observation of the stimulation of hair follicles and the greater expression of growth factors, in another study, where the use of ozonized oil was compared to a control group, for the treatment of wounds in guinea pigs [9].

\section{MANUFACTURERS}

${ }^{1}$ Ouro Fino Saúde Animal Participações S.A. Cravinhos, SP, Brazil. ${ }^{2}$ União Química Farmacêutica Nacional S/A. São Paulo, SP, Brazil. ${ }^{3}$ Vetnil Indústria e Comércio de Produtos Veterinários Ltda. Louveira, SP, Brazil.

${ }^{4}$ Clarion Biociências Ltda. Aparecida de Goiânia, GO, Brazil.

${ }^{5}$ Medquímica Indústria Farmacêutica Ltda. Juiz de Fora, MG, Brazil. ${ }^{6}$ Respond Systems Incorporated. Branford, CT, USA.

${ }^{7}$ Ozone \& Life Indústria, Comércio e Sistemas Ltda. São José dos Campos, SP, Brazil.

Declaration of interest. The authors report no conflicts of interest. The authors alone are responsible for the content and writing of this paper.

\section{REFERENCES}

1 Alves G.E.S., Abreu J.M.G., Ribeiro Filho J.D., Muzzi L.A.L., Oliveira H.P., Tannus R.J. \& Buchanan T. 2004. Efeitos do ozônio nas lesões de reperfusão do jejuno em eqüinos. Arquivo Brasileiro de Medicina Veterinária e Zootecnia. 56(4): 433-437.

2 Amalsadvala T. \& Swain S.F. 2006. Management of hard-to-heal wounds. Veterinary Clinics of North America Small Animal Practice. 36(4): 693-711.

3 Andrade F.S.S.D., Clark R.M.O \& Ferreira M.L. 2014. Efeitos da laserterapia de baixa potência na cicatrização de feridas cutâneas. Revista do Colégio Brasileiro de Cirurgiões. 41(2): 129-133.

4 Anzolin A.P. \& Bertol C.D. 2018. Ozone therapy as an integrating therapeutic in osteoartrosis treatment: a systematic review. Brazilian Journal of Pain. 1(2): 171-175.

5 Benvindo R., Braun G., Carvalho A \& Bertolini G. 2008. Efeitos da terapia fotodinâmica e de uma única aplicação de laser de baixa potência em bactérias in vitro. Fisioterapia e Pesquisa. 15(1): 53-57.

6 Bocci V.A. 2005. Scientific and Medical Aspects of Ozone Therapy. State of the Art. Archives of Medical Research. 37(4): 425-435.

7 Cunha A.P., Silva A.P. \& Roque O.R. 2012. Plantas e Produtos Vegetais em Fitoterapia. 4.ed. Lisboa: Fundação Calouste Golbenkian, 729p.

8 Hawkins D.H. \& Abrahamse H. 2006. The role of laser fluence in cell viability, proliferation, and membrane integrity of wounded human skin fibroblasts following helium-neon laser irradiation. Lasers in Surgery and Medicine. 38(1): 74-83.

9 Kim H.S., Noh S.U., Han Y.W., Kim K.M., Kang H., Kim H.O. \& Park Y.M. 2009. Therapeutic Effects of Topical Application of Ozone on Acute Cutaneous Wound Healing. Journal of Korean Medical Science. 24(3): 368-374.

10 Kosachenco B., Calliari C., Appel B. \& Mentz F.M.E. 2018. Efecto terapéutico de la Ozonoterapia en la cicatrización de heridas en perros: Reporte de casos. Revista Española de Ozonoterapia. 8(1): 197-210.

11 Lima A.M.S., Lima M.K.F., Oliveira J.G.O., Moreira Y.F., Cavalcante T.O., Silva A.C.A. \& Escodro P.B. 2018. Ozonioterapia em ferida associada à periostite infecciosa em um equino. In: Anais da V Semana de Medicina Veterinária da Universidade Federal de Alagoas (Macéio, Brazil). p.49.

12 Lopes A. \& Lopes L.A. 2006. Técnica da drenagem linfática ativada por laserterapia. In: Dib L.L. \& Saddy M.S. (Eds). Atualização Clínica em Odontologia. 24.ed. Porto Alegre: Artes Medicas, pp.1-12.

13 MacPhil C.M. 2013. Surgery of the integumentary system. In: Fossum T.W. (Ed). Small Animal Surgery. 4th edn. Saint Louis: Elsevier-Mosby, pp.190-288.

14 Menéndez S., León O.S. \& Hernández F. 2008. Mecanismos de acción biológica y efectos terapéuticos del ozono. In: Menéndez S. (Ed). Ozono: aspectos básicos y aplicaciones clínicas. Habana: CENIC, pp.40-107. 
15 Menezes F.F. 2006. Avaliação da Calendula officinalis L. na cicatrização cutânea de cães. Aspectos clínicos, histopatológicos e histoquímicos. 82f. Recife, PE. Tese (Doutorado em Ciência Veterinária) - Programa de Pós-Graduação em Ciência Veterinária, Universidade Federal Rural de Pernambuco.

16 Mercês P.L., Araújo L.A., Araújo A.C.V., Santos M.H.A.S., Lemes S.R. \& Melo-Reis P.R.M. 2017. Avaliação da atividade cicatricial do Aloe vera em feridas em dorso de ratos. Estima. 15(1): 35-42.

17 Nitz A.C., Ely J.B., D'acampora A.J., Tames D.R. \& Corrêa B.P. 2006. Estudo morfométrico no processo de cicatrização de feridas cutâneas em ratos, usando: Coronopus didymus e Calendula officinalis. Arquivos Catarinenses de Medicina. 35(4): 74-79.

18 Oliveira Junior J.O. \& Lages G.V. 2012. Ozonioterapia em lombociatalgia. Revista Dor. 13(3): 261-270.

19 Piso D.Y.T., Restán W.A.Z. \& Barreto M.Y.P. 2016. Implantes de membranas biológicas en cirugía reconstructiva veterinaria: aspectos básicos y métodos de conservación. Revista Medicina Veterinária. 1(31): 105-120.

20 Rabelo R.E., Silva T.D.P., Sant'ana F.J.F., Oliveira S.L., Leão H.F., Kanashiro T.C.B., Silva O.C. \& Costa Y.L. 2006. Uso do barbatimão na cicatrização de feridas cutâneas iatrogênicas em cães. In: Anais eletrônicos do XIV Seminário de Iniciação Cientifica (Goiânia, Brazil). n.p.

21 Re L., Martínez-Sánchez G., Bordicchia M., Malcangi G., Pocognoli A., Morales-Segura M.A. \& Rothchild J.R.A. 2014. Is ozone pre-conditioning effect linked to Nrf2/EpRE activation pathway in vivo? A preliminary result. European Journal of Pharmacology. 742(8): 158-162.

22 Re L., Martínez-Sánchez G. \& Mawsouf N. 2011. Clinical evidence of ozone interaction with pain mediators. Saudi Medical Jornal. 31(12): 1363-1367.

23 Rocha Júnior A.M., Oliveira R.G., Farias R.E., Andrade L.C.F. \& Aarestrup F.M. 2006. Modulação da proliferação fibroblástica e da resposta inflamatória pela terapia a laser de baixa intensidade no processo de reparo tecidual. Anais Brasileiros de Dermatologia. 81(2): 150-156

24 Rodrigues D.F., Mendes F.F., Noronha Filho A.D.F. Silva J.A. \& Silva L.A.F. 2013. O extrato da casca de barbatimão, Stryphnodendron adstringens (Martius) Coville, na cicatrização de feridas em animais. Enciclopédia Biosfera. 9(16): 1583-1601.

25 Santos T.C.C. 2016. Spray e gel a 2\% de quitosana na cicatrização de feridas cutâneas em ratas diabéticas. 59f. Goiânia, GO. Dissertação (Mestrado em Ciência Animal) - Programa de Pós-graduação em Ciência Animal, Universidade Federal de Goiás.

26 Schwartz A. 2017. Manual de Ozonoterapia Clínica. Madrid: Editorial Medizeus, 651p.

27 Scwhartz A. \& Martínez-Sánchez G. 2012. La ozonoterapia y su fundamentación científica. Revista Española de Ozonoterapia. 2(1): 163-198.

28 Sunnen G. 1988. Ozone in medicine: overview and future directions. Journal of Advancement in Medicine. 1(3): 159-174.

29 Wendt S.B.T. 2005. Comparação da eficácia da calêndula e do óleo de girassol na cicatrização por segunda intenção de feridas em pequenos animais. 83f. Curitiba, PR. Dissertação (Mestrado em Ciências Veterinárias) - Programa de Pós-Graduação em Ciências Veterinárias, Universidade Federal do Paraná. 